\begin{tabular}{ll}
\hline \hline MINING AND METALLURGY INSTITUTE BOR & ISSN: 2334-8836 (Štampano izdanje) \\
UDK: 622 & ISSN: 2406-1395 (Online) \\
\hline \hline
\end{tabular}

UDK: $622.272 / .45(045)=111$

doi: $10.5937 / \mathrm{mmeb} 2002035 \mathrm{~T}$

\author{
Vladimir Todorović, Jelena Trivan ${ }^{* *}$, Dražana Tošić ${ }^{* *}$, Figun Ljubica ${ }^{* *}$

\section{CHARACTERISTICS OF THE MAIN FANS OF THE ACTIVE UNDERGROUND MINES JP PEU - RESAVICA}

\begin{abstract}
Ventilation is a very important phase in mining from the point of view of continuous works in the underground mines and safety of the employees. For the ventilation of the active underground mines of JP PEU Resavica the artificial ventilation is used with the main fans installed within the ventilation in active plants. According to the characteristics of the ventilation networks, the appropriate main fans were also selected. In this paper, the characteristics of fans in the active underground mines and an analysis of their works are presented, and the suggestions for their improvement are given within the discussion.
\end{abstract}

Keywords: coal mine, underground mine, mine ventilation, fan, fan characteristics

\section{INTRODUCTION}

In a complex process of ventilation design of an underground mine, it is important to process systematically, followed by the phases: the selection of ventilation methods, the ventilation scheme selection, analysis of parameters of influence for ventilation system design, calculation of required quantities of air by parts of ventilation network and total, air velocity, analysis of depression ratio, the selection of main and auxiliary fan, definition of separate ventilation, method and organization of ventilation control and presentation the economic parameters for the designed ventilation system.

For the choice of the main fans, the basic element is a dynamic development of mining (exploitation) works, there the fan should satisfy the safety and economic effects. This primarily refers to a slight change in the air volume flow, depression and coefficient of efficiency.
The purchase of the main fan is associated with the age of mine, which complicates the selection process. Also, the operation of fan must be constant and stable, and in case of excessive situations the procedure of manipulation with the fan and during the air flow in response to the resulting disturbances should be developed.

In the active mines of JP PEU Resavi$\mathrm{ca}$, the main ventilation systems have been established artificially, depressed with the main fans, while a diagonal air control system is present in the all facilities. In this case, different types of fans from different manufactures have been applied in practice, and in this paper, systematization of the types and characteristics is performed, considering that so far this not been done in the technical and project documentation. Namely, the ventilation projects were done partially in the mines, and there was a need to show the applied

\footnotetext{
* JPPEU Resavica

** University of Banja Luka, Faculty of Mining Prijedor
} 
main fans in one place and give the suggestions for improvements.

\section{MINING FANS}

Turbomachines used for mechanical ventilation of the mines by establishing the air flow called the mine fans. The mine fans are used for the main ventilation (main fan), special-separate ventilation (pipe fans) and regulation the air distribution in the ventilation network (auxiliary fan).

The mine fans are classified into a number of groups and categories according to the principle of construction (centrifugal, axial), location of installation (above ground and underground), capacity (small, medium and large), depression (small, medium and high), power of the drive motor (low, medium and high power), coefficient of efficiency (low, medium and high economic).

In relation to its working possibilities, one fan is defined by a diagram of characteristics that correspond to the different speeds and different angles of blades rotation, and consist of three curves: curve of the air flow dependences on depression, power motor curve and efficiency curve. Today, the predominant types of axial fans are in use, since they are defined as the multistage by their construction, which creates an adequate depression, and they have a drawback of construction the centrifugal fans.

During the operation of the main fan, changes in the air flow and depression are achieved in several modes:

- changing the speed of the main fan,

- changing the angle of rotor blades,

- changing the equivalent opening of the mine (characteristic of the ventilation network).

In a larger mine, ventilation is sometimes established by the joint operation of several fans (serial, parallel operation), which requires the careful regulation. Figure 1 presents a layout of one fan for the main ventilation, while Figure 2 presents a diagram of the operating characteristics.

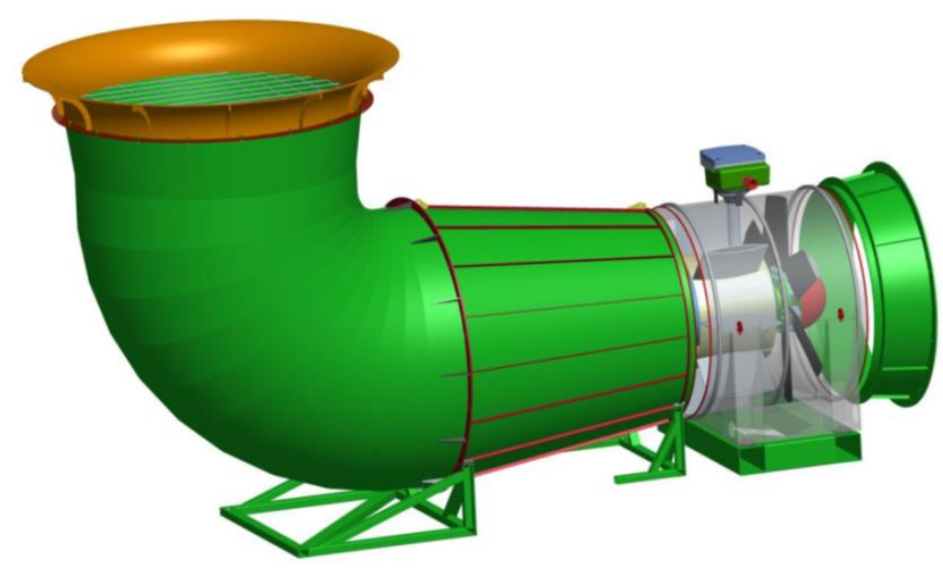

Figure 1 Layout of the main fan type AVJ 1500-6-75 in the Štavalj mine 



Figure 2 Diagram of the operating characteristics of the main fan type AVJ 1500-6-75

\section{RESEARCH OF THE \\ CHARACTERISTICS OF THE MAIN FANS INSTALLED IN THE ACTIVE MINES IN JP PEU}

In the mine ventilation design, it is important to take into account the technological scheme of the underground mine, applied systems and dynamics of exploitation and especially the analysis of natural conditions.

From the aspects of ventilation, the following natural conditions related to the coal seam and surrounding rocks are important
- depth of incline,

- gas content (especially methane content and methane abundance),

- characteristics of coal dust (explosiveness, flammability),

- natural tendency towards to selfignition.

The analysis of the natural conditions led to the results given in Table 1 . 
Table 1 Overview of the basic natural conditions influencing to the ventilation design and choice of the main fan

\begin{tabular}{|c|c|c|c|c|c|}
\hline \multirow[b]{2}{*}{$\begin{array}{c}\text { Mine- } \\
\text { underground }\end{array}$} & \multicolumn{5}{|c|}{ Natural conditions } \\
\hline & $\begin{array}{l}\text { Depth of } \\
\text { inline (m) }\end{array}$ & $\begin{array}{l}\text { Methane } \\
\text { bearing } \\
\left(\mathrm{m}^{3} / \text { tru }\right) \\
\end{array}$ & $\begin{array}{c}\text { Dust } \\
\text { explosiveness } \\
\left(g / \mathbf{m}^{3}\right) \\
\end{array}$ & $\begin{array}{c}\text { Dust self- } \\
\text { ignition } \\
\left({ }^{\circ} \mathrm{C}\right) \\
\end{array}$ & $\begin{array}{c}\text { Coal self- } \\
\text { ignition } \\
\left({ }^{\circ} \mathrm{C} / \mathrm{min}\right) \\
\end{array}$ \\
\hline $\begin{array}{l}\text { Vrška Čuka } \\
\text {-underground mine } \\
\text { Avramica }\end{array}$ & up to 270 & 10 & Non-explosive & $\begin{array}{l}\text { Not self- } \\
\text { ignition }\end{array}$ & $\begin{array}{l}\text { Not self- } \\
\text { ignition }\end{array}$ \\
\hline $\begin{array}{l}\text { Ibar Mines } \\
\text {-undeground mine } \\
\text { Jarando }\end{array}$ & 470 & 0,24 & $70-110$ & $630-700$ & $69-98$ \\
\hline $\begin{array}{l}\text { RMU "Rembas" - } \\
\text { underground mine } \\
\text { Senjski rudnik }\end{array}$ & 350 & $\begin{array}{l}\text { Registered } \\
\text { appearance }\end{array}$ & 200 & $260-290$ & $118-140$ \\
\hline $\begin{array}{l}\text { RMU "Rembas" - } \\
\text { undeground mine } \\
\text { Strmosten }\end{array}$ & 480 & $\begin{array}{l}\text { Registered } \\
\text { appearance }\end{array}$ & 180 & $280-290$ & $110-120$ \\
\hline $\begin{array}{l}\text { RMU "Rembas"- } \\
\text { undergound mine } \\
\text { Ravna Reka }\end{array}$ & 250 & $\begin{array}{l}\text { Registered } \\
\text { appearance }\end{array}$ & 75 & 250 & $55-95$ \\
\hline $\begin{array}{l}\text { Mine Bogovina-- } \\
\text { underground mine } \\
\text { Ist. polje }\end{array}$ & 240 & $\begin{array}{l}\text { Registered } \\
\text { appearance }\end{array}$ & 225 & 250 & $80-120$ \\
\hline $\begin{array}{l}\text { Mine Soko-- } \\
\text { underground mine } \\
\text { Soko }\end{array}$ & 450 & $1.8-7.1$ & 230 & $250-350$ & $115-188$ \\
\hline $\begin{array}{l}\text { Mine Jasenovac- } \\
\text { underground mine } \\
\text { Jasenovac }\end{array}$ & 220 & $\begin{array}{l}\text { Non- } \\
\text { methane }\end{array}$ & 225 & 260 & $80-100$ \\
\hline $\begin{array}{l}\text { Mine Lubnica - } \\
\text { underground mine } \\
\text { Osojno }\end{array}$ & 200 & $\begin{array}{l}\text { Registered } \\
\text { appearance }\end{array}$ & 110 & $215-235$ & 80 \\
\hline $\begin{array}{l}\text { Mine Štavalj - } \\
\text { underground mine } \\
\text { Štavalj }\end{array}$ & 280 & $\begin{array}{l}\text { Non- } \\
\text { methane }\end{array}$ & - & $220-280$ & $103-111$ \\
\hline
\end{tabular}

According to the depth of the works, which determines the lengths of air flow line, most of the underground mines belong to the medium deep mines, with the deepest underground mines as Strmosten, Jarando and Soko.

By measuring the gas condition, the mines Avramica, Jarando and Soko were categorized as methane and with a methane mode of activities, while in the mines Štavalj and Jasenovac no methane appearance was found. In the other mines, only methane appearance was registered, and in low limits which categorized them as the non-methane.

Coal dust in all mines, except the Avramica mine, shows the explosive and flammable characteristics in certain conditions, which are reflected in the solutions in the field of ventilation. Coal of coal seams in all mines, except the Avramica mine, showed a risk of endogenous fire, which was confirmed by the results of numerous tests and large number of fires in almost all mines. 
The fans for the main ventilation of mines, especially those with appearance of explosive gases and explosive coal dust are constructed precisely according to the regulations, standards, norms and rules. The fan plants consist of the main and auxiliary fan, a device for changing the air flow, ventila- tion duct, energy supply equipment and equipment for registration and control of fan operating parameters. By control the mine ventilation plants revealed that the main and auxiliary fans of different types and several manufactu-rers were installed, which is shown in Table 2.

Table 2 Layout of the characteristics of installed fans for the main ventilation in the mines of JP PEU

\begin{tabular}{|c|c|c|c|c|c|c|c|}
\hline \multirow[b]{2}{*}{ Mine } & \multirow[b]{2}{*}{ Fan } & \multicolumn{6}{|c|}{ Parameters } \\
\hline & & Fan type & Manufacturer & $\begin{array}{c}\text { Capacity } \\
\left(\mathrm{m}^{3} / \mathrm{s}\right)\end{array}$ & $\begin{array}{l}\text { Depress. } \\
\text { (Pa) }\end{array}$ & $\begin{array}{c}\text { Rating } \\
(\mathbf{k W})\end{array}$ & $\begin{array}{c}\text { Engine } \\
\text { speed } \\
(\% / \mathrm{min})\end{array}$ \\
\hline \multirow{2}{*}{$\begin{array}{l}\text { Vrška Čuka } \\
\text {-underground } \\
\text { mine Avramica }\end{array}$} & main & & $\begin{array}{l}\text { Ventilator- } \\
\text { Zagreb }\end{array}$ & 12 & 488 & 37 & 520 \\
\hline & auxiliary & & $\begin{array}{l}\text { Ventilator- } \\
\text { Zagreb }\end{array}$ & 12 & 488 & 37 & 520 \\
\hline \multirow{2}{*}{$\begin{array}{l}\text { Ibar Mines } \\
\text {-underground } \\
\text { mine Jarando }\end{array}$} & main & AV-1000 & & 20 & 1200 & 45 & 1460 \\
\hline & auxiliary & AV-1000 & & 20 & 1200 & 45 & 1460 \\
\hline \multirow{2}{*}{$\begin{array}{l}\text { RMU "Rembas" } \\
\text { - underground } \\
\text { mine Senjski } \\
\text { rudnik }\end{array}$} & main & AVV-12-154-2 & Klima Celje & 23 & 1030 & 55 & 1480 \\
\hline & auxiliary & AVV-12-125-4 & Klima Celje & 28 & 500 & 22 & 985 \\
\hline \multirow{2}{*}{$\begin{array}{l}\text { RMU "Rembas" } \\
\text { - underground } \\
\text { mine Strmosten }\end{array}$} & main & AVV-12-125-4 & Klima Celje & 40 & 2700 & 75 & 1500 \\
\hline & auxiliary & & & & & & \\
\hline \multirow{2}{*}{$\begin{array}{l}\text { RMU "Rembas" } \\
\text { - underground } \\
\text { mine Ravna } \\
\text { Reka }\end{array}$} & main & N-HVV-D-125 & Klima Celje & 40 & 1000 & 30 & 1460 \\
\hline & auxiliary & & & & & & \\
\hline \multirow{2}{*}{$\begin{array}{l}\text { Mine Bogovina } \\
\text { - underground } \\
\text { mine Istočno } \\
\text { polje }\end{array}$} & main & N-AVV-D-125 & Klima Celje & 23 & 800 & 30 & 975 \\
\hline & auxiliary & N-AVV-D-125 & Klima Celje & 23 & 800 & 30 & 1460 \\
\hline \multirow{2}{*}{$\begin{array}{l}\text { Mine Soko-- } \\
\text { undreground } \\
\text { mine Soko }\end{array}$} & main & GVh-15-160 & Turman & 83 & 2800 & 160 & 1460 \\
\hline & auxiliary & $\mathrm{CN}-125$ & Termo-elektro & 38 & 1460 & 50 & 1460 \\
\hline \multirow{2}{*}{$\begin{array}{l}\text { Mine Jasenovac } \\
\text { - underground } \\
\text { mine Jasenovac }\end{array}$} & main & N-AVV-D-125 & Klima Celje & 23 & 800 & 30 & 1460 \\
\hline & auxiliary & N-AVV-D-125 & Klima Celje & 23 & 800 & 30 & 1460 \\
\hline \multirow{2}{*}{$\begin{array}{l}\text { Mine Lubnica - } \\
\text { underground } \\
\text { mine Osojno }\end{array}$} & main & AVJ-1500(45) & Delta Air & $10-40$ & 2800 & 55 & 1470 \\
\hline & auxiliary & SC-160 & Minel BG & 15 & 500 & 30 & 1445 \\
\hline \multirow{2}{*}{$\begin{array}{l}\text { Mine Štavalj - } \\
\text { underground } \\
\text { mine Štavalj }\end{array}$} & main & AVJ-1500-6-75 & Delta Air & $10-40$ & 2800 & 55 & 1470 \\
\hline & auxiliary & NAVV-D-140/56 & Klima Celje & 40 & 880 & 75 & 980 \\
\hline
\end{tabular}

\section{DISCUSSION}

Mine ventilation has the main task of constantly changing the air flow in all mines through a continuous movement of air to maintain a climate suitable for work, to dilute harmful and dangerous gases and take them to the surface. In the all mines of JP PEU, the main fans with associated equipment are used, which establishes the appro- 
priate artificial ventilation. The equipment and devices inspection and appropriate measurements within ventila-tion systems of the characteristics of fans and their operation mode of the existing intensity of work have determined. Based on the above, for the first time, the data of the main fans were systematized in one place and a comparison of the determined parameters was performed.

The analysis of development options of active underground mines in JP PEU estimates that the prospective underground mines Soko, Štavalj, Lubnica and Strmosten have the adequate coal reserves, while the other underground mines are about to close, outsourced of the remaining reserves, and a special attention should be paid to the equipment and devices for ventilation of the prospective underground mines.

The obtained results indicate that in the Soko mine, when designing the intensity of mining operation and natural-geological conditions, the limitations may appear, related to the characteristics of the main fan and increased intensity of the mining operations.

\section{CONCLUSION}

The subject of research within of this topic are the characteristics of the main and auxiliary fans, as well as other equipment within the ventilation plants of the active underground mines of JP PEU Resavica, in order to assess their operational readiness for the normal support of ventilation systems.

For the current intensity of mining operations in the mines, the ventilation systems are able to provide the necessary amount of air for work and dilution of the harmful gases concentrations. No restrictions are expected from the analysis of the development plans, except in the Soko mine, where the amount of air delivered by the main fan at the upper limits is for the current scope of work.
Installed fans are mostly of older constructions and have been in operation for many years (over 40 years), except in the mines Stavalj and Lubnica (up to 10 years) and Soko (30 years), and the process of air current reversion is slow and difficult to satisfy the regulations on the main fans. This requires the changes that would address these shortcomings.

\section{REFERENCES}

[1] Ivković M. (1977): The Rational Systems of Underground Mining of the Brown Coal Seams of Large Thickness in the Complex Exploitation Conditions. Doctoral Dissertation, University of Belgrade Faculty of Mining and Geology Belgrade (Serbia).

[2] Vukobratović T. (1998): Mine Ventilation (selected chapters). Institute for Copper (Serbia)

[3] Đinović K., Cvjetić A. (2006): Exploitation of Mine Fans, University of Belgrade, Faculty of Mining and Geology Belgrade (Serbia)

[4] Jovičić V. (1989): Mine Ventilation, Textbook, University of Belgrade, Faculty of Mining and Geology Belgrade, Serbia.

[5] Miljanović J., Ivković M. (2014): Systematization of TechnicalTechnological Solutions of Exploitation in Underground Coal Mines in Serbia, Monograph, Committee for Underground Exploitation of Raw Materials Resavica (Serbia)

[6] Miljković M., Ignjatović M., Bogdanović T., Vukobratović T. (2009): Safety and Mine ventilation, Monograph, MMI, Bor, (in Serbian) 